Canadian

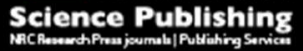

Botany

Botanique

\title{
Sugar maple (Acer saccharum) at its northeastern range limit: a fire-resilient tree species
}

\begin{tabular}{|r|l|}
\hline Journal: & Botany \\
\hline Manuscript ID & cjb-2018-0016.R1 \\
\hline Manuscript Type: & Article \\
\hline Date Submitted by the Author: & 13 -Mar-2018 \\
\hline Complete List of Authors: & $\begin{array}{l}\text { Payette, Serge; Université Laval, Département de biologie } \\
\text { Frégeau, Mathieu; Université Laval, Département de biologie } \\
\text { Couillard, Pierre-Luc; Ministère des Forêts, de la Faune et des Parcs, } \\
\text { Direction des inventaires forestiers } \\
\text { Pilon, Vanessa; Universite Laval, Département de biologie } \\
\text { Laflamme, Jason; Ministère des Forêts, de la Faune et des Parcs, Direction } \\
\text { des inventaires forestiers }\end{array}$ \\
\hline $\begin{array}{r}\text { Is the invited manuscript for } \\
\text { consideration in a Special } \\
\text { Issue? : }\end{array}$ & N/A \\
\hline Keyword: & Acer saccharum, earthworm, forest fire, Holocene, resilience \\
\hline \multicolumn{2}{|c}{} \\
\hline \multicolumn{2}{|c|}{} \\
\hline
\end{tabular}

SCHOLARONE ${ }^{\text {m }}$

Manuscripts 


\section{Sugar maple (Acer saccharum) at its northeastern range limit: a fire-resilient tree species}

\section{Serge Payette, Mathieu Frégeau, Pierre-Luc Couillard, Vanessa Pilon and Jason Laflamme}

S. Payette, M. Frégeau and V. Pilon. Département de biologie and Centre d'études nordiques, Université Laval, 1045, av. de la Médecine, Québec, QC G1V 0A6, Canada.

P.-L. Couillard and J. Laflamme. Direction des inventaires forestiers, Ministère des Forêts, de la Faune et des Parcs, 5700 4e ave ouest, Québec, QC G1H 6R1, Canada.

Corresponding author: Serge Payette (email: serge.payette@bio.ulaval.ca). 


\begin{abstract}
The long-standing hypothesis that sugar maple (Acer saccharum) communities are maintained at equilibrium by present climate and small-scale disturbances is questioned as empirical evidence is accumulating about the ability of the species to withstand several stand-scale disturbances. The fire history of a sugar maple site at the northeastern range limit of the species (Gaspé Peninsula, eastern Canada) was documented to test the hypothesis that this forest type is resilient to fire disturbance. The fire history was reconstructed using radiocarbon-dated soil macrocharcoals. Two main fire periods were recorded during the Holocene. The oldest period occurred between 9055 and 8265 cal. years BP, and was characterized by the presence of conifers, including spruce. After 6900 years of fire-free activities, the second period covered the last 1335 years, and was characterized by the presence of sugar maple in the charcoal assemblage. The dominance of sugar maple after more than 1000 years of recurrent fires underlines the species resilience to frequent site disturbances. The soil of the forest stand was heavily disturbed by earthworms. However, the dense seedling and sapling bank of sugar maple suggests that earthworms do not affect negatively the regeneration and survival of the species.
\end{abstract}

Key words: Acer saccharum, earthworm, forest fire, Holocene, resilience, advance regeneration.

Résumé : L'hypothèse voulant que les érablières (Acer saccharum) soient à l'équilibre avec le climat actuel et les perturbations à fine échelle est de plus en plus remise en question par les données empiriques montrant la capacité de l'espèce de se régénérer après des perturbations à l'échelle des peuplements. L'histoire des feux d'une station dominée par l'érable à sucre à la limite nord-est de son aire naturelle (Péninsule gaspésienne, Est canadien) a été reconstituée afin de tester l'hypothèse de sa résilience face aux feux. La radiodatation de macrocharbons (identifiés botaniquement) du sol de la forêt a servi à la reconstitution. Les feux sont survenus à l'Holocène inférieur, entre 9055 et 8265 ans avant aujourd'hui, et ont brûlé des conifères. Après une longue période sans feu, ces derniers ont repris à l'Holocène supérieur. Cette deuxième période, de 1335 ans à aujourd'hui, est caractérisée par la forte présence de l'érable à sucre dans l'assemblage 
macrofossile. La dominance de l'espèce après plusieurs feux récurrents souligne sa résilience face à ce type de perturbation. Actuellement, le sol de la forêt est fortement perturbé par les vers de terre. Cependant, l'importante régénération préétablie suggère que l'activité des vers de terre n'affecte pas la régénération et la survie de l'érable à sucre.

Mots-clés : Acer saccharum, feux de forêt, Holocène, régénération préétablie, résilience, ver de terre. 


\section{Introduction}

The main distributional range of sugar maple (Acer saccharum) covers the temperate areas of eastern North America, from the Great-Lake states to Alabama and northern Georgia and New England in eastern U.S. (Little 1971; Hart et al. 2014), and the cool and temperate areas of southern Ontario and Quebec in Canada (Farrar 1995; Marie-Victorin 1995). The easternmost limit of the species is in northern Cape Breton Island (Greenidge 1961), whereas highly disjunct sugar maple populations (subsp. skutchii) thrive in tropical mountainous areas of Latin America (Vargas-Rodrigez and Platts 2012). Such a large distribution across the North-American continent is a direct biogeographical legacy of late Tertiary and Pleistocene climatic changes (VargasRodrigez et al. 2015), and underlines the species ability to withstand and adapt to a diversity of environmental conditions.

The long-standing hypothesis that sugar maple communities are relatively stable and maintained at equilibrium by present climate and small-scale disturbance regime (Grandtner 1966; Mosseler et al. 2003) is questioned as empirical evidence is accumulating about the ability of the species to withstand several types of disturbance. Sugar maple is tolerant of shade conditions of the forest environment (Forcier 1975; Bellefleur and Villeneuve 1984; Beaudet and Messier 1998). The species responds readily to local disturbances induced by windthrows and windsnaps (Canham 1985; Payette et al. 1990), and also to larger disturbances caused by clearcut (Albert and Barnes 1987; Bannon et al. 2015; Pilon et al. 2018), ice storm (Beaudet et al. 2007) and fire (Pilon and Payette 2015). Current shady and locally sun-exposed forest environments across the species range provide a diversified suite of favorable conditions for its regeneration, growth and survival across a continuum of stand disturbances (Nolet et al. 2008). Near its northern distribution limit in the Bas-Saint-Laurent area (eastern Quebec), the abundance of sugar maple increased significantly during the $20^{\text {th }}$ century, particularly in high-altitude sites (DelisleGagnon 2014). Rapid regional expansion of the species was promoted by current forestry 
practices focusing on selective harvesting of conifer trees (Boucher et al. 2006; Delisle-Gagnon 2014). Whether sugar maple is presently expanding north of its range limit under present climatic warming, in this region and elsewhere in eastern Canada, remains unknown and needs to be documented. On the other side of the species range in southern US, sugar maple populations are stable under current climatic and site conditions, without contraction or expansion of regional populations (Hart et al. 2014).

Similar to the Bas-Saint-Laurent situation (Boucher et al. 2006; Delisle-Gagnon 2014; Pilon et al. 2018), sugar maple is thriving as an important companion species within the regional boreal-prone forest complex of the Gaspé Peninsula, in eastern Quebec (Pinna et al. 2009). Although less abundant than in the Bas-Saint-Laurent region and southern Quebec, sugar maple forms discrete forest stands in association with yellow birch (Betula alleghaniensis) in the Gaspé Peninsula, particularly in the Forillon National Park (Fig. 1) (Majcen 1981; Lévesque 1997; Quenneville and Thériault 2008). According to Asnong and Richard (2003), the species migrated in the Gaspé area at least 5000 years ago, but its abundance decreased regionally over the last 3000 years, possibly due to increased fire frequency. By selecting a sugar maple site situated at the northeastern limit of the species in the Appalachian mixed boreal zone of the Gaspé Peninsula, we were interested to evaluate the resilience of the species to stand disturbances, particularly fire as the major driving factor of community change at the scale of the Holocene. As a case study, our main objective was to question the status and the origin of a sugar maple stand within the yellow-birch-balsam fir (Abies balsamea) forest domain (Grondin et al. 1999) in the Forillon National Park, i.e., whether the species population is declining or resilient in the face of fire disturbance. To do so, we proceeded to the reconstruction of the Holocene fire history and tree species composition of the sugar maple forest site based on the macrofossil analysis of soil charcoals. 


\section{Methods}

\section{Study area}

The bedrock surrounding the study site is composed of metamorphosed schists dating from the Appalachian orogeny that occurred during the lower Paleozoic era (Cambro-Ordovician rocks) (D'Hulst 2007). A heterometric, loam-textured glacial deposit (till) lies on the bedrock. The Forillon sugar maple forest is located in the vicinity of Gaspé Bay, which was completely frozen over during the last ice age. Deglaciation of the region took place 15000 years ago, and Gaspé Bay became ice free 1000 years later (Houde-Poirier 2014). The marine limit of the Goldthwait Sea in the Anse-au-Griffon valley, located immediately north of Gaspé Bay, varied from 26 to 37 m above its current level (Houde-Poirier 2014).

The vegetation cover of the Gaspé Peninsula has a boreal facies with a clear dominance of balsam fir stands in mesic environments, with the exception of the uplands of the interior where subalpine vegetation, represented by white spruce (Picea glauca) stands, and alpine vegetation primarily cover hillsides above 900-1000 m (Payette and Boudreau 1984; de Lafontaine and Payette 2010). The balsam fir-yellow birch bioclimatic domain lies around the periphery of the Gaspé Peninsula, the balsam fir-paper birch (Betula papyrifera) domain in the interior (Pinna et al. 2009). A few temperate species such as sugar maple, red oak (Quercus rubra) and white pine (Pinus strobus) are distributed in small, isolated, sporadic populations along the maritime coastline (Fortin et al. 2009; Pinna et al. 2009; Tremblay-Daoust 2011). Few forest ecosystems undisturbed by human activity remain following exploitation of natural resources on the Gaspé Peninsula over the last two centuries (Desjardins et al. 1999; Pinna et al. 2009). Under natural conditions, windthrow and insect epidemics represent the main factors disturbing the forest dynamics of Gaspé ecosystems, since fires are less frequent in the region. 
For several centuries, European colonization has been the principal disturbance factor in the region's forest landscapes, particularly land clearing by settlers for subsistence farming, logging, and deliberate or accidental fires. Thus, not long after the first Europeans arrived, around 1560, several families had already settled permanently in the region bordering Gaspé Bay (Roy and Breault 1934 in Pinna et al. 2009).

\section{Sampling}

The Forillon site $\left(48^{\circ} 52^{\prime} 48^{\prime \prime} \mathrm{N}, 64^{\circ} 22^{\prime} 86^{\prime \prime} \mathrm{W}\right)$ was selected based on ecoforest maps of the Quebec Government showing the distribution and size of mature sugar maple stands. The stand was sampled in September 2016. Species represented in the stand were inventoried. The size structure of the sugar maple forest was determined based on diameter at breast height (DBH) of all arborescent species within a plot measuring $1000 \mathrm{~m}^{2}(20 \mathrm{~m}$ x $50 \mathrm{~m})$. Sugar maples with a $\mathrm{DBH}<2 \mathrm{~cm}$ (saplings and seedlings) were recorded in 10 sub-plots, each $5 \mathrm{~m}^{2}$, for a total area of $50 \mathrm{~m}^{2}$, whereas individuals from all other species were enumerated in the $1000 \mathrm{~m}^{2}$ plot. The number of sugar maple saplings and seedlings was extrapolated to the area covered by the sample plot. All saplings and seedlings of balsam poplar (Populus balsamifera) were also enumerated in 4 sub-plots, each $5 \mathrm{~m}^{2}$, whereas mature individuals are in proximity, but outside the sampling plot. Core samples were taken at a height of $30 \mathrm{~cm}$ above the soil surface from 30 trees selected based on the largest diameters in the stand, specifically 17 sugar maple, 4 yellow birch, 2 paper birch (from outside the plot), 2 balsam spruce and 5 white spruce.

Wood macroremains (stems, stumps and large branches) in a standing position or on the ground in the sample plot were inventoried. Any organic matter (including litter) covering the macroremains was removed in order to evaluate the diameter and degree of decomposition of each piece of wood. The depth at which each piece was buried (not buried, partially buried, buried) and evidence of fire (wood charcoal) or cutting were noted. Five classes of 
decomposition were identified in the macroremains following the criteria of Pyle and Brown (1998): 1. bark firmly attached to stem, wood shows no sign of decomposition; 2 . bark detached; solid stem does not change under pressure, wood shows signs of decomposition only in center of trunk or at point of contact with ground; 3 . bark absent; wood is spongy and tends to splinter; wood surface flexible under pressure but regains its usual shape once removed; 4 . Piece of wood detached into several large fragments that break easily, partially flattened and powdery; 5 . more than $85 \%$ of wood is powdery, residual wood fragments no more than a few centimeters long; stem completely crushed and flat. The soil in the sugar maple stand was described and analyzed following Canadian soil classification norms (SCCS 2002).

Wood charcoal sampling was performed at 25 microsites. Of these, 22 were situated along two lines $50 \mathrm{~m}$ long that delimited the edges of the plot; the other three microsites were positioned at $5 \mathrm{~m}$ between each other in the plot center. After leaf litter was removed, soil samples were collected using a soil auger. Three overlapping soil cores (totalling $750 \mathrm{~cm}^{3}$ per core) of organic matter (surface organic horizon) and mineral soil were collected at each microsite in order to extract wood charcoal pieces. Samples referred to as "A" are from the top of the soil profile (0 to $15 \mathrm{~cm}$ in depth) and samples "B" and "C" are from cores collected respectively at depths of $15 \mathrm{~cm}$ and $30 \mathrm{~cm}$ below the soil surface. "A" samples are primarily composed of mixed mineral and organic matter, a mixture that can be attributed to earthworm activity (Ah horizon). Only three sites yielded an intact fibrous and humic organic horizon characteristic of the podzolic soils generally found in a sugar maple forest. All samples were immersed in a $\mathrm{NaOH}(2-5 \%)$ solution, then boiled for at least 12 hours, in order to facilitate dispersal of aggregates and eliminate organic matter during sifting. All samples were also sifted under a jet of water using $2 \mathrm{~mm}$ and $4 \mathrm{~mm}$ screens. Wood charcoals, all of macroscopic size greater than $2 \mathrm{~mm}$, and showing signs of having been formed in situ rather than transported over long distances (Ohlson et Tryterud 2000), were extracted manually using a binocular magnifier, 
and air dried. Wood charcoal pieces extracted by sifting and retained for botanical identification were selected following the three anatomical wood categories using an incident light microscope (200 and 500x). The anatomical characteristics of wood pieces described by Hoadley (1990), Inside Wood (2004) and Panshin and Zeeuw (1980), as well as the charcoal wood reference collection of the Centre d'études nordiques («Center for Northern Studies», Université Laval, Quebec) were used for botanical identification of charcoals. Charcoals were identified to genus or species when possible. The degree of weathering evident in wood pieces (vitrification, reaction wood, physical deterioration), their small size and orange-colored deposits present in the structure of the wood are the main factors that rendered identification of the charcoals difficult.

\section{Dating and fire history}

The wood charcoals were selected for ${ }^{14} \mathrm{C}$ dating (accelerator mass spectrometry) according to the taxa present, their distribution on the site and their stratigraphic position in each microsite. Selected charcoals were pretreated at the Radiochronology Laboratory of the Centre for Northern Studies, and then dated at the lab of the Keck Carbon Cycle AMS Facility (University of California, Irvine, California, USA).

Calib7.02 (Stuiver et al. 2013) software and the IntCal13 (Reimer et al. 2013) database were used to calibrate the ${ }^{14} \mathrm{C}$ dates in calendar years. For each of the ${ }^{14} \mathrm{C}$ dates $( \pm 2$ standard deviations), the distribution of calendar ages was considered according to the probabilistic states provided by the software. The distribution of calendar ages is generally fractionated into probabilistic states due to variations in atmospheric ${ }^{14} \mathrm{C}$ content associated to solar activity (Solanki et al. 2004). The calendar year interval with the greatest probability was used to determine sample age. The average of this interval was considered the calibrated year BP of the dated sample in relation to the reference year BP, which is 1950 . The charcoals with most probable calendar age intervals overlapping by at least 10 to 20 years were considered to originate from the same fire. 
Given the particular distribution of the charcoals in a forest environment subject to windthrow and other disturbances that alter soil stratigraphy (Payette et al. 2012), it is preferable to date the greatest number of charcoals possible, in order to record all fires that have occurred over the course of time. Given the numerous constraints that prevent dating all wood charcoals extracted from the ground, it is more practical to use an indirect method to evaluate the total number of fires that have occurred on a site over time. In order to estimate the actual number of fires that occurred on the site, non-parametric estimators (NPE) of the number of undetected fires were calculated. The use of NPE is recommended when the distribution of the frequency of species is unkown (Chao and Chiu 2016). The Homogenous indicator is a parametric estimator of diversity. The results of this estimator are similar to those obtained by estimating the real number of fires that occurred on the site by regression of an accumulation curve. The Chaol-bc indicator is a conservative NPE that estimates minimal specific richness. The ACE-1, jackknife-1 and jackknife-2 indices are based on the frequency of rare species (here, charcoals) and are used for estimating real specific richness. Estimators, including standard deviations and 95\% confidence intervals, were calculated using the R software extension SpadeR (R Development Core Team 2008; Chao and Chiu 2016).

\section{Results}

The general characteristics of the Forillon maple stand are presented in Table 1. The physical and chemical characteristics of the soil (Table 2) show that it formed from an Appalachian till corresponding to an acidic podzol that was well drained (drainage class 2), relatively poor in mineral elements, with a loamy and rocky texture in which limes (Ah and Ae horizons) and clays (B horizon) predominated. In some places, the soil surface comprises an L horizon (litter) 0-2 cm thick, but consists primarily of an Ah horizon of mineral and organic matter. The FH horizon, 0$15 \mathrm{~cm}$ thick, which is so common in sugar maple soils, is replaced over most of this site by an Ah horizon of granular structure, $10-15 \mathrm{~cm}$ thick that can be attributed to earthworm activity. The 
latter are particularly numerous, as only three microsites retain the integral, natural soil horizonation, including an FH horizon, an Ae horizon and a B horizon (Fig. 2). The list of primary plant species growing in the stand is shown in Table 3.

\section{Structure of the sugar maple stand}

The arborescent strata, which is relatively closed (about $60-70 \%$ cover), consists of four different species: sugar maple, yellow birch, balsam fir and white spruce. Sugar maple, by far the dominant species in the stand, shows an inverse-J size structure (Fig. 3), an indication of an uneven-aged population. Over 54 sugar maple stems have a diameter $>2 \mathrm{~cm}$, of which 28 are $>20 \mathrm{~cm}$; the largest individual has a diameter of 66-68 $\mathrm{cm}$. Only four yellow birch exceed a diameter of $3 \mathrm{~cm}$, and the largest has a diameter of 60-62 cm. Eighteen balsam firs have a diameter $>2 \mathrm{~cm}$, and they are uniformly distributed throughout the stand; the largest stem has a diameter of $34-36 \mathrm{~cm}$. There are seven stems of white spruce with a diameter larger than $2 \mathrm{~cm}$, the largest no more than $26 \mathrm{~cm}$ in diameter. Sugar maple represents $82 \%$ of the basal area (stems $>2 \mathrm{~cm}$ at DBH) of the population, and the other tree species $8 \%$ or less each.

The advance regeneration (bank of seedlings and saplings) of sugar maple is considerable, with an estimated total (based on the 10 plots used for enumeration purposes) of 32 360 individuals. The stand's other tree species are under-represented in the regeneration strata, each with 10 individuals or less. The balsam poplar bank of saplings and seedlings includes 41 individuals inventoried in four enumeration subplots. These individuals are growing in proximity to seed-bearing trees situated outside the sampling quadrat.

The shrub strata, represented by a large number of species, including sugar maple and mountain maple (Acer spicatum) (Table 3), clearly predominates in the understory, whereas the herbaceous strata includes several ferns, among them Dryopteris, Phegopteris and Gymnocarpium, and is rather sparse. Mosses and lichens are present only on rocks or trunks. 
Very few trunks lie on the ground, and there are few openings in the forest cover $(\sim 30 \%$ of the total cover).

The 17 sugar maples from which core samples were taken varied in age from 80 to 130 years, but in fact established at an earlier date, since sampling was conducted at $30 \mathrm{~cm}$ above the soil surface (Table 4). Yellow birch, paper birch and balsam fir generally had ages less than 100 years, whereas three of the five white spruce sampled were over 100 years old. The oldest tree in this stand is a white spruce of 142 years that probably established well before 1874 .

\section{Wood macroremains}

The mounds and hollows of the soil surface are linked to windthrow, which, along with windsnap, is responsible for the trees and branches strewn about on the forest floor. Over 20 woody macroremains were recorded on the soil surface (Fig. 4). The diameter of the pieces of wood varies from $2-4 \mathrm{~cm}$ to $66-68 \mathrm{~cm}$. None of the macroremains shows signs of cutting or fire. Conifers represent $78 \%$ of the macroremain assemblage, specifically balsam fir (56\%) and white spruce $(22 \%)$. However, pieces of wood from deciduous species account for only $22 \%$ of the reservoir of macroremains, specifically $13 \%$ birch, $4 \%$ sugar maple and $4 \%$ ash (of which live individuals are present only outside of the sampling plot). Pieces of wood are divided respectively among decomposition classes 1 to 5 in the following proportions: $9 \%, 17 \%, 43 \%, 26 \%$ and $4 \%$ (Fig. 5). Conifers predominate in the classes reflecting advanced decomposition, classes 3, 4 and 5. The sole sugar maple lying on the soil surface is partially covered by a thin layer of leaf litter and is in decomposition class 4 . The majority of the conifers are partially or totally buried. As would be expected, the most decomposed macroremains are those that are completely or partially buried.

\section{Charcoal inventory}


A total of 247 charcoal pieces were recorded in the sample plot and distributed among 11 of the 25 microsites (Table 5). More than half of the pieces are from deciduous species (59\%), of which sugar maple alone accounts for $53 \%$ of all the charcoals inventoried on the site. Only $4 \%$ of wood charcoals are from conifers, and among these only balsam fir and spruce are represented. Over $37 \%$ of the wood charcoals could not be identified botanically due to the absence of distinctive anatomical characteristics. More than 130 charcoals (or $52 \%$ of the charcoals on the site) of sugar maple were from only two microsites. The same is true for unidentified pieces, of which the vast majority (35\% of all the charcoals on the site) were found in only two microsites. It should be noted that 63 unidentified wood charcoals (or $26 \%$ of all charcoals on the site) were from the same microsite where 82 pieces from deciduous species (especially sugar maple) were inventoried; this microsite thus held 145 of the 247 wood charcoals (or 59\%) in the entire sample plot. These unusual findings underline the extremely heterogenous pattern of wood charcoal distribution.

Fire periods

Twelve fires were recorded on the sugar maple site. Four of them occurred between 9055 and 8265 years ago, at an average interval of 200 years (Table 6, Fig. 5). Three of the four fires are represented by spruce charcoals (Picea sp.), and the other, the oldest, by a wood charcoal of unknown botanical origin. No fires were identified for the period from 8265 to 1335 years ago, which represents a fire-free interval of almost 6925 years. In contrast, eight fires occurred between 1335 years ago and today, which corresponds to a relatively short average interval of 165 years.

The current forest has thus been evolving in a context of fire disturbance for at least the last 1300 years. The three fires from the second millennium are represented by wood charcoals of unknown botanical origin, by bark (or a piece of cone) and by a single deciduous species. Sugar 
maple has been present on the site for at least 530 years, according to wood charcoals dating from that period, an indication of the resilience of the species to fire disturbance.

The parametric estimator Homogenous indicates that approximately 12 fires occurred on the site, which in fact corresponds to the number of fires recorded. However, indices Chaol-bc, $A C E-1$, and Jackknife 1 and 2 show that between 17 and 21 fires occurred on the site, suggesting that 5 to 9 fires were not identified (Table 7). It should be noted that the standard deviation and confidence interval of $95 \%$ for these indices are quite high, which can no doubt be attributed to the small number of datings. The non parametric estimators indicate that the fire history is probably incomplete, but it appears difficult to obtain a reliable measurement of the actual number of fires that occurred.

\section{Discussion}

During the Holocene, the sugar maple site at Forillon National Park recorded 12 different fires. Although it is probable that more occurred, this is difficult to determine based on a calculation of the theoretical number of fires estimated by the rarefaction curve. Consequently, it is important to stress that the fire history of this site is probably incomplete despite radiocarbon dating of numerous macroscopic wood charcoals. Analysis of these charcoals, however, makes it possible to provide a general description of fire incidence in the Forillon region situated north of the municipality of Gaspé.

Based on analysis of the macrocharcoals, the fire history of the Forillon region includes two main periods, the oldest from 9055 to 8265 years ago, and the more recent from 1335 years ago up until the present time. At least 6900 years separate the two fire periods. The first forests that burned during the lower Holocene were probably composed of conifers, especially spruces, while those of the upper Holocene were dominated by sugar maple and conifers including balsam fir. The Forillon site's pattern of fire frequency resembles that of a nearby site located on Île Bonaventure, 
near the small city of Percé, at least in regard to an ancient period of fire activity that lasted from 8400 to 7800 years ago (Tremblay et al. 2014). This direct proof of fire incidence during the lower and the upper Holocene also confirms the abundance of microscopic charcoals from around 8500 years ago and from 2500 years ago until today, collected by Asnong and Richard (2003) from a small lake near the municipality of Gaspé. The same paleofire tendencies characterize the Bas-StLaurent region, situated west of the Gaspé Peninsula, and is highlighted by peaks in microcharcoal abundance in several lakes at the beginning of the Holocene (Richard et al. 1992). The same fire frequency is again observable in macrocharcoal datings from the beginning of the Holocene in the region situated in the countryside around Rimouski, in the Saguenay, as well as in the greater Quebec City region (Talon et al. 2005; Pilon and Payette 2015; Payette et al. 2016; 2017). The Mont-St-Pierre sugar maple site, also located in the northern part of the Gaspé Peninsula, shows a fire history resembling that of Forillon during the last millennium, where 6-8 fires occurred at an interval of 120-150 years (Pilon and Payette 2015). Furthermore, the mid-Holocene does not seem to have been a period favorable to propagation of fires, based on the fire record in all of these regions. It is probable that the climate of the period was more humid, at least during the summer, thereby decreasing the chances of ignition and propagation of fires by lightning. At the Forillon site and in the Gaspé region (Asnong and Richard 2003), the lower and upper Holocene are probably the only periods with high fire frequency before and after the long quiescent interval that prevailed during the middle Holocene.

Using pollen data, Asnong and Richard (2003) reported a marked increase in conifers from 3000 years ago to present, particularly spruce, balsam fir and even jack pine, a species absent from the region except in the form of an abundance of pollen grains, which may suggest the species expanded its range elsewhere through the action of fires. Farther west, in the Bas-St-Laurent region, which was marked by close contact between temperate and boreal forest flora, sugar maple was more abundant during the mid-Holocene than it is today, although even then it was not 
predominant in these areas (Richard et al. 1992). It is probable that some thermophilous species from the Gaspé region, such as sugar maple and red oak, also took hold in the balsam fir-yellow birch bioclimatic domain from the beginning of the mid-Holocene, around 5000 years ago, without reaching regional dominance. According to Asnong and Richard (2003), the abundance of these species has diminished over the last 3000 years possibly due to fires.

Several fires moved through the Forillon site over the course of the last two millennia. Three ancient fires occurred at the turn of the second millennium, from 1335 to 1035 years ago, at close intervals of 100 years. More than half a millennium later, 500-600 years ago, five different fires occurred at the same average interval that characterized the passage of fire around the year 1000. Some reservation must be expressed here when distinguishing among the most recent fires, considering the difficulties associated with using radiocarbon in radiometric dating, since its atmospheric concentration has fluctuated considerably over the last 200-300 years (Solanski et al. 2004). Despite a high fire frequency for this type of vegetation, it is probable that these last fires were of relatively low intensity and covered a small area. According to the inventory of charcoals, sugar maple was present in each of the populations that burned in the last 500-600 years, an indirect proof of the species' resilience and ability to regenerate after fire. However, age data on the oldest trees of the current stand and from the numerous wood charcoals dating from this period are insufficient for determining the botanical composition of all the forests that were present on this site, and then burned, prior to the last fire that occurred around the middle of the $19^{\text {th }}$ century. In this regard, it is probable that the last fire on the Forillon site occurred in the 1840 s, which is, incidentally, a period for which fire was reported in Forillon National Park by Tremblay-Daoust (2011). It is possible that this fire was of human origin, given the forestry activity that intensified at the time in the Anse-au-Griffon valley (Mimeault 1995).

Anse-au-Griffon was part of the first «seigneuries» (vast tracks of land of the French regime) granted in the Gaspé Peninsula, in 1668. The Anse-au-Griffon valley was open for 
colonization from 1850 to 1970 (Mimeault 1995), that is, right up until the lands were expropriated by the Canadian federal government during expansion of the national parks network (Babin 2015). Agricultural activity began around 1855, but selective logging was also an important economic activity during the 120 years the valley was inhabited, along with operation of some 20 mills and sawmills (Mimeault 1995). Together, they profoundly influenced the dynamics of forest stands (Majcen 1981). Sugar maple and yellow birch were among the tree species most coveted by the industry, whereas later, conifers (balsam fir and spruce) were sought as the pulp and paper industry expanded in the region (Mimeault 1995). The first sawmills began operating in Gaspé in 1775 (Desjardins et al. 1999). Resource exploitation in the Anse-au-Griffon valley during the 120 years of its occupation and prior to 1850 clearly had considerable impact on the composition of the original forest (Majcen 1981; Lévesque 1997). Stumps of all sizes can still be found in these forests, an indication of systematic logging of conifers, particularly during the 1940s and 1950s (Lévesque 1997). According to Pinna et al. (2009), five major fires affected the forests of the Gaspé Peninsula between 1850 and 1950. However, fires were infrequent in the region; the majority were of anthropic origin and affected a variable surface area. Some studies of fire frequency in Forillon National Park report a fire rotation (or fire cycle) on the order of 600 years (Groupe Dryade 1986 in Pinna et al. 2009), but the data used to arrive at this figure have yet to be validated.

The Forillon sugar maple forest established around the middle of the 19th century and is currently an uneven-aged stand. The abundance of sugar maple in all strata of the stand, from the forest canopy to the advance regeneration, is an indication of the species' ability to persist under sunny as well as shady conditions, whether in the presence or absence of disturbances such as fire and windthrow. Although no sign of logging was observed in the stand, sugar maple would have been able to regenerate after this type of disturbance in the Forillon region, as several studies on this subject have reported elsewhere in eastern Québec (Boucher et al. 2006; Delisle-Gagnon 2014; 
Pilon et al. 2018). Wood macroremains on the soil surface show a predominance of conifers, but it is impossible to confirm the existence of a predominantly coniferous mixed forest at the time of the 1840s fire. The dominance of sugar maple in the current population does suggest, however, that the original forest and its surroundings would have included a large number of seed-bearing individuals capable of regenerating the species.

An increase in the abundance of deciduous species to the detriment of conifers has been reported in the Gaspé Peninsula and elsewhere in Québec, under both natural conditions and after logging (Brisson and Bouchard 2003; Boucher et al. 2006; Delisle-Gagnon 2014; Pilon et al. 2018). Sugar maple regenerates after severe disturbances that affect the forest canopy, such as fire, windthrow, windsnap and logging. Even forest clearing followed by vegetation eradication using herbicides for at least three years does not prevent sugar maple from establishing and persisting (Reiners 1992), which illustrates the species' resistance and resilience to very frequent, intense disturbances.

We do not know the composition of the forest that occupied the Forillon site during the 6900 years preceding the fire that occurred 1335 years ago. It is probable that a mixed forest composed of conifers, notably balsam fir, and deciduous species, including sugar maple, would have persisted on the site, at least until the passage of the last fire, 150 years ago. Most of the wood charcoals produced during the last fire are sugar maple, with a few other deciduous species, balsam fir and bark of unknown origin. According to the charcoal record, sugar maple became the dominant, or one of the dominant, species in the populations that have now occupied the Forillon site for the last 500-600 years. While it is currently not possible to determine the origin of the fires that occurred during this period, it is probable that at least one of them was due to human activity. However, it appears that no anthropic influence, such as systematic logging, modified the course of forest succession on the Forillon site in recent centuries. Based on these facts on the recent 
disturbance history, sugar maple populations surrounding the Forillon site likely increased over the last centuries, instead of being reduced by fire.

One last factor that deserves to be emphasized regarding the evolution of the Forillon sugar maple stand is earthworm activity. Numerous endogeic earthworms (including Lumbricus terrestris) were observed in 22 of the 25 microsites from which wood charcoals were extracted. Examination of the soils revealed extensive disturbance caused by earthworm activity, notably by thorough mixing of the soil horizons. Soil mixing resulted in profound transformation of the upper part of the solum, where a portion of the original organic $(\mathrm{F}, \mathrm{FH}$ and $\mathrm{H})$ and mineral (Ae and $\mathrm{B}$ ) horizons was transformed into an Ah horizon resembling the superficial horizon of soils under cultivation (Fig. 2). The earthworms in the Forillon forest no doubt originated in former farmlands of the Anse-au-Griffon valley, where agricultural activities flourished in the $19^{\text {th }}$ and $20^{\text {th }}$ centuries; they would have been dispersed passively over time, as well as actively by birds. Earthworms such as Lumbricus terrestris, which live in the soil of deciduous forests of the temperate and even the boreal zone, originated in Europe and were introduced in North America in recent centuries by European settlers (Langmaid 1964; Hale et al. 2005; Drouin et al. 2016). The impact of earthworms has been the subject of numerous studies, which have demonstrated their destructive effect on the normal biological activity of the forest soil (Eisenhauer et al. 2007). The ecological impact of earthworms on the soils of the Forillon sugar maple forest is unknown, other than the evident transformation of the solum observed during the course of this study. Damage of sugar maple crowns has been reported recently in temperate forests of Wisconsin and Michigan, and could be attributable to earthworm activity (Bal et al. 2018). Worms modify edaphic (physical and chemical) conditions considerably by mixing organic material with mineral soil. Their action affects plant growth by consuming roots and rootlets, a process that has been documented in sugar maple (Bal et al. 2018). Destruction of the surficial organic horizon and resulting exposure of the mineral soil (horizon Ah) probably constitute important factors that can affect the potential for regeneration and 
growth of a number of understory plants (Drouin et al. 2016). However, the normal habit of adult sugar maples and the strong regeneration of the species in the understory of the Forillon stand suggest that the negative ecological impact of earthworms on sugar maple has yet to be demonstrated. Furthermore, we do not know how disturbing the soil and exposing the mineral soil in the sugar maple forest can influence the diversity, establishment, survival and growth of the herbaceous plants and several tree species that generally grow in this type of forest.

Despite ecosystemic conservation measures put in place through the creation of Forillon National Park, the Anse-au-Griffon valley bears the signature of anthropic activity, and will do so for a long time to come. The indelible marks are not only a result of fires set accidentally over the course of the last two centuries, and selective logging for the last 100 years, but also through the earthworms that are reminders of its agricultural past.

\section{Conclusion}

Based on an ecological and paleoecological analysis of the Forillon National park site that presently hosts a sugar maple forest comprising both sugar maple and yellow birch, the following main conclusions can be drawn. The fire history of the Forillon site includes two main periods of activity, the first during the lower Holocene, from 9055 to 8265 years ago, and the second during the upper Holocene, from 1335 years ago until today. A long period of quiescence between the two lasted more than 6900 years. The Forillon site burned on three occasions around the first millennium, and possibly on five occasions during the last 500-600 years, with an average fire cycle of 100 years during these two periods. The vegetation cover affected by the fires of the lower Holocene was predominantly coniferous, whereas that of the last 500-600 years was marked by the presence of sugar maple, possibly predominant locally, based on the floristic composition of wood 
charcoals from this period. However, coniferous macroremains in the current population suggest that, relatively recently, the stand had a mixed facies. The current structure and composition of the forest seem to be the result of the dominance of sugar maple and its coexistence with conifers, the dominant species throughout the forests of the Gaspé Peninsula. Sugar maple predominates today, and, under current conditions, it is uncertain whether conifers could take that role in the context of a demographic equilibrium maintained by fires and windthrow, as is the case today. Frequent fires in the lower Holocene underline the instability of air masses that prevailed during this period. The increase in the number of fires during the upper Holocene can probably be attributed to a higher frequency of episodes of summer drought, even though these were interspersed with heavy precipitation. Fire recurrence during the upper Holocene thus appears to confirm a borealization of forest ecosystems. Anthropic activities had and continue to have an impact on the structure of the Forillon sugar maple stand and soils, possibly through the influence of the most recent fire and the introduction of earthworms. The dominance of the Forillon sugar maple population underlines the resilience of the species to highly disturbed environments.

\section{Acknowledgements}

Our sincere thanks to Jocelyn Gosselin from the Forest Inventory Management Department of the Québec Ministry of Forests, Fauna and Parks, for having initiated this research and encouraged the study of fires and their history across southern Québec. Louise Filion was of invaluable assistance in the field. A special thanks to the authorities at Forillon National Park (Environment Canada), especially Daniel Sigouin, park ecologist, for granting us access to the sampling site, and for valuable information on the forest vegetation and recent history of forestry activities in the region. Without his crucial contribution, this project could not have been completed. We are most gratefull to external reviewers for their constructive comments on an earlier draft of the paper. 


\section{References}

Albert, D.A., and Barnes, B.V. 1987. Effects of clearcutting on the vegetation and soil of a sugar maple-dominated ecosystem, western Upper Michigan. For. Ecol. Manage. 18(4): 283-298.

Asnong, H., and Richard, P.J.H. 2003. La végétation et le climat postglaciaires du centre et de l’est de la Gaspésie, au Québec. Géogr. Phys. Quat. 57(1): 37-63.

Babin, A. 2015. L'expropriation du territoire de Forillon. Les décisions politiques au détriment des citoyens. Les Presses de l’Université Laval. Québec, Canada.

Bal, T. L., Storer, A.J., and Jurgensen, M.F. 2018. Evidence of damage from exotic invasive earthworm activity was highly correlated to sugar maple dieback in the Upper Great Lakes region. Biol. Invasions, 20(1): 151-164 DOI: 10.1007/s10530-017-1523-0.

Bannon, K., Delagrande, S., Bélanger, N., and Messier, C. 2015. American beech and sugar maple sapling relative abundance and growth are not modified by light availability following partial and total canopy disturbances. Can. J. For. Res. 45(6): 632-638.

Beaudet, M., Brisson, J., Messier, C., and Gravel, D. 2007. Effect of a major ice storm on understory light conditions in an old-growth Acer-Fagus forest: pattern of recovery over seven years. For. Ecol. Manage. 242(2): 553-557.

Beaudet, M., and Messier, C. 1998. Growth and morphological responses of yellow birch, sugar maple, and beech seedlings growing under a natural light gradient. Can. J. For. Res. 28(7): 1007-1015. 
Bellefleur, P., Villeneuve, M. 1984. Évolution des taux de croissance juvénile d'espèces forestières sous trois régimes expérimentaux de compétition. Ann. Sci. For. 41(4): 427-438.

Boucher, Y., Arseneault, D., and Sirois, L. 2006. Logging-induced change (1930-2002) of a preindustrial landscape at the northern range limit of northern hardwoods, eastern Canada. Can. J. For. Res. 36(2): 505-517.

Brisson, J., and Bouchard, A. 2003. In the past two centuries, human activities have caused major changes in the tree species composition of southern Québec, Canada. Écoscience, 10(2): 236-246.

Canham, C.D. 1985. Suppression and release during canopy recruitment in Acer saccharum. Bull. Torr. Bot. Club, 112: 134-145.

Chao, A., and Chiu, C.-H. 2016. Nonparametric estimation and comparison of species richness.in eLS. John Wiley \& Sons, Ltd. Chichester, UK.

de Lafontaine, G., and Payette, S. 2010. The origin and dynamics of subalpine white spruce and balsam fir stands in boreal eastern North America. Ecosystems, 13(6): 932-947.

Delisle-Gagnon, V. 2014. Expansion de l'érable à sucre (Acer saccharum Marsh.) à la limite nordique de son aire de répartition, au Bas-Saint-Laurent (Québec). M.Sc. Thesis, Université du Québec à Rimouski. Rimouski, Québec, Canada.

Desjardins, M., Frenette, Y., Bélanger, J., and Hétu, B. 1999. Histoire de la Gaspésie. $2^{\mathrm{e}}$ édition. Les Presses de l’Université Laval. Québec, Canada. 
D’Hulst, A. 2007. Métallogénie des gîtes dévoniens du dôme de Lemieux et de SainteMarguerite, Gaspésie, Québec, Canada. Ph.D. Thesis, Université Laval. Québec, Québec, Canada.

Drouin, M., Bradley, R., and Lapointe, L. 2016. Linkage between exotic earthworms, understory vegetation and soil properties in sugar maple forests. For. Ecol. Manage. 364: 113-121.

Eisenhauer, N., Partsch, S., Parkinson, D., and Scheu, S. 2007. Invasion of a deciduous forest by earthworms: Changes in soil chemistry, microflora, microarthropods and vegetation. Soil Biol. Biochem. 39(5): 1099-1110.

Farrar, J.L. 1995. Trees in Canada. Fitzhenry \& Whiteside Limited. Markham, Ontario, Canada.

Forcier, L.K. 1975. Reproductive strategies and the co-occurrence of climax tree species. Science, 189(4205): 808-810.

Fortin, S., Côté, M., and Brodeur, S. 2009. Le chêne rouge à Forillon : découverte de nouveaux sites. Nat. Can. (Qué), 133(1): 12-17.

Grandtner, M.M. 1966. La végétation forestière du Québec meridional. Presses de l’Université Laval, Québec, Canada.

Greenidge, K.N.H. 1961. Patterns of distribution of sugar maple, Acer saccharum Marsh., in northern Cape Breton Island. Am. Midl. Nat. 66: 138-151.

Grondin, P., Blouin, J., and Racine, P. 1999. Rapport de classification écologique du sousdomaine bioclimatique de la sapinière à bouleau jaune de l'est. Ministère des Ressources naturelles du Québec. Québec, Canada. 
Hale, C.M., Frelich, L.E., Reich, P.B., and Pastor, J. 2005. Effects of European earthworm invasion on soil characteristics in northern hardwood forests of Minnesota, USA. Ecosystems, 8(8): 911-927.

Hart, J.I., Oswalt, C.M., Turberville, C.M. 2014. Population dynamics of sugar maple through the southern portion of its range: implications for range migration. Botany, 92(8): 563-569.

Hoadley, R.B. 1990. Identifying Wood: Accurate Results with Simple Tools. Taunton Press, Newtown, Connecticut, USA.

Houde-Poirier, M. 2014. Écoulements glaciaires au Wisconsinien supérieur, déglaciation et variations d'un niveau marin relatif dans la région de Gaspé, Québec. M.Sc. Thesis, Université du Québec à Rimouski. Rimouski, Québec, Canada.

Inside Wood 2004 - present. http://insidewood.lib.ncsu.edu/search

Langmaid, K.K. 1964. Some effects of earthworm invasion in virgin podzols. Can, J. Soil Sci. 44(1): 34-37.

Lévesque, F. 1997. Conséquences de la dynamique de la mosaïque forestière sur l'intégrité écologique du Parc national Forillon. M.Sc. Thesis, Université Laval. Québec, Québec, Canada.

Little, E.L. 1971. Atlas of United States trees. In Conifers and Important Hardwoods. Vol. 1. U.S. For. Serv. Misc. Publ. No. 1146.

Majcen, Z. 1981. Les forêts du parc national Forillon, Gaspésie, Québec. Étude phytosociologique. Laboratoire d'écologie forestière, Université Laval. Québec, Québec, Canada. 
Marie-Victorin, F. 1995. Flore laurentienne. Presses de l’Université de Montréal. Montréal, Québec, Canada.

Ministère des Forêts, de la Faune et des Parcs du Québec, 2017. Cartes écoforestières, 4e inventaire forestier. Direction des inventaires forestiers, Québec, Québec, Canada.

Mimeault, M. 1995. Historique de l'exploitation agro-forestière de la vallée de l'Anse-au-Griffo, Gaspé. Parcs Canada. Ottawa, Ontario, Canada.

Mosseler, A., Lynds, J.A., and Major, J.E. 2003. Old-growth forests of the Acadian Forest region. Environ. Rev. 11(S1): S47-S57.

Nolet, P., Delagrande, S., Bouffard, D., Doyon, F., and Forget, É. 2008. The successional status of sugar maple (Acer saccharum), revisited. Ann. For. Sci. 65(2): 208. DOI:

10.1051/forest:2007091

Ohlson, M., and Tryterud, E. 2000. Interpretation of the charcoal record in forest soils: Forest fires and their production and deposition of macroscopic charcoal. Holocene, 10(4): 519-525.

Panshin, A.J., and de Zeeuw, C. 1980. Textbook of Wood Technology. $4^{\text {th }}$ edition. McGraw-Hill. New York, New York, USA.

Payette, S., and Boudreau, F. 1984. Évolution postglaciaire des hauts sommets alpins et subalpins de la Gaspésie. Can. J. Earth Sci. 21(3): 319-335.

Payette, S., Delwaide, A., Schaffhauser, A., and Magnan, G. 2012. Calculating long-term fire frequency at the stand scale from charcoal data. Ecosphere, 3(7): art. 59. 
Payette, S., Filion, L., and Delwaide, A. 1990. Disturbance regime of a cold temperate forest as deduced from tree ring patterns: the Tantaré Ecological Reserve, Quebec. Can. J. For. Res. 20(8): $1228-1241$.

Payette, S., Pilon, V., Couillard, P.-L., and Frégeau, M. 2016. Long-term fire history of maple (Acer) forest sites in the central St. Lawrence Lowland, Quebec. Can. J. For. Res. 46(6): 822-831. Payette, S., Pilon, V., Couillard, P.-L., and Laflamme, L. 2017. Fire history of Appalachian forests of the Lower St-Lawrence region (southern Quebec). Forests, 8(4): art. 120.

Pilon, V., and Payette, S. 2015. Sugar maple (Acer saccharum) forests at their northern distribution limit are recurrently impacted by fire. Can. J. For. Res. 45(4): 452-462.

Pilon, V., Payette, S., Couillard, P.-L., and Laflamme, J. 2018. Surface analysis as a method to reconstruct past and recent dynamics of forest ecosystems. For. Ecol. Manage. 407: 84-94.

Pinna, S., Malenfant, A., Hébert, B., and Côté, M. 2009. Portrait forestier historique de la Gaspésie. Consortium en foresterie Gaspésie-Les-Îles. Gaspé, Québec, Canada.

Pyle, C., and Brown, M.M. 1998. A rapid system of decay classification for hardwood logs of the eastern deciduous forest floor. J. Torr. Bot. Soc. 125: 237-245.

Quenneville, R., and Thériault, M. 2008. Plan de gestion du feu. Parc national du Canada Forillon. Parc Canada. Service de la conservation des écosystèmes. Gaspé, Québec, Canada.

R Development Core Team 2011. R: A Language and Environment for Statistical Computing. R Foundation for Statistical Computing. Vienna, Austria.

Reimer, P.J., Bard, E., Bayliss, A. et al. 2013. IntCal13 and Marine13 radiocarbon age calibration curves 0-50000 years cal. B.P. Radiocarbon, 55(4): 1869-1887. 
Reiners, W.A. 1992. Twenty years of ecosystem reorganization following experimental deforestation and regrowth suppression. Ecol. Monogr. 62(4): 503-523.

Richard, P.J.H., Larouche, A.C., and Lortie, G. 1992. Paléophytogéographie et paléoclimats postglaciaires dans l'ouest du Bas-Saint-Laurent, Québec. Géogr. Phys. Quat. 46(2): 151-172.

SCCS 2002. Le système canadien de classification des sols. $3^{\text {th }}$ edition. Agriculture et Agroalimentaire Canada. Conseil national de recherche du Canada. Ottawa, Ontario, Canada.

Solanki, S.K., Usoskin, I.G., Kromer, B., Schüssler, M., and Beer, J. 2004. Unusual activity of the sun during recent decades compared to the previous 11,000 years. Nature, 431(7012): 10841087.

Stuiver, M., Reimer, P.J., and Reimer, R.W. 2013. CALIB 7.02. http://radiocarbon.pa.qub.ac.uk/calib/

Talon, B., Payette, S., Filion, L., and Delwaide, A. 2005. Reconstruction of the long-term fire history of an old-growth deciduous forest in southern Québec, Canada, from charred wood in mineral soils. Quat. Res. 64(1): 36-43.

Tremblay, J., Lavoie, M., and Frégeau, M. 2014. Historique à long terme des feux de forêt de la sapinière de l'île Bonaventure en Gaspésie. Naturaliste canadien, 138(2): 26-31.

Tremblay-Daoust, A. 2011. Dynamique du chêne rouge à sa limite nordique de distribution naturelle au parc national Forillon, Gaspésie (Québec). M.Sc. Thesis, Université du Québec à Rimouski. Rimouski, Québec, Canada. 
Vargas-Rodriguez, Y.L., and Platt, W.J. 2012. Remnant sugar maple (Acer saccharum subsp. skutchii) populations at their range edge: characteristics, environmental constraints and conservation implications in tropical America. Biol. Conserv. 150(1): 111-120.

Vargas-Rodriguez, Y.L., Platt, W.J., Urbatsch, L.E., and Foltz, D.W. 2015. Large scale patterns of genetic variation and differentiation in sugar maple from tropical Central America to temperate North America. BMC Evol. Biol. 15(1): 257. DOI 10.1186/s12862-015-0518-7 
Table 1. Physical characteristics of the Forillon sugar maple forest.

\begin{tabular}{lc}
\hline Altitude (m) & 145 \\
Slope & $15^{\circ}$ \\
Aspect & east \\
Organic horizon thickness (cm) & $0-15$ \\
pH of F horizon & 3.9 \\
pH of B horizon & 4.2 \\
Soil texture (B horizon) & Clay loam \\
\hline
\end{tabular}


Table 2. Soil characteristics of the Forillon sugar maple stand.

\begin{tabular}{|c|c|c|c|c|c|}
\hline \multirow{2}{*}{\multicolumn{2}{|c|}{ Characteristics }} & \multicolumn{4}{|c|}{ Horizon } \\
\hline & & $\mathrm{FH}$ & $\mathrm{Ah}$ & $\mathrm{Ae}$ & $\mathrm{Bf}$ \\
\hline Sand & \multirow{4}{*}{$\%$} & / & 41 & 15 & 21 \\
\hline Coarse silt & & / & 8 & 20 & 13 \\
\hline Fine silt & & I & 37 & 44 & 30 \\
\hline Clay & & 1 & 14 & 21 & 36 \\
\hline Soil texture & & 1 & Loam & Loamy loam & Clay loam \\
\hline $\mathrm{Ca}$ & \multirow{6}{*}{ 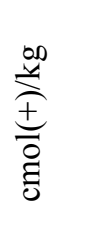 } & 15.4 & 8.0 & 1.7 & 4.5 \\
\hline $\mathrm{Mg}$ & & 2.6 & 1.7 & 0.5 & 0.9 \\
\hline K & & 1.2 & 0.8 & 0.1 & 0.2 \\
\hline $\mathrm{Na}$ & & 0.9 & 0.2 & 0.2 & 0.2 \\
\hline $\mathrm{H}^{+}$ & & 4.5 & 1.5 & 0.6 & 1.8 \\
\hline $\mathrm{CEC}^{1}$ & & 24.7 & 12.2 & 3.1 & 7.6 \\
\hline $\mathrm{BS}^{2}$ & $\%$ & 81.9 & 88.1 & 79.4 & 75.8 \\
\hline \multirow{2}{*}{$\mathrm{pH}$} & $\mathrm{H}_{2} \mathrm{O}$ & 3.91 & 3.81 & 3.93 & 4.19 \\
\hline & $\mathrm{CaCl}_{2}$ & 2.98 & 3.02 & 3.31 & 3.59 \\
\hline $\mathrm{Al}$ (pyro) & \multirow{2}{*}{ ppm } & 1614 & 683 & 212 & 2222 \\
\hline $\mathrm{Fe}$ (pyro) & & 3759 & 2005 & 563 & 10805 \\
\hline $\mathrm{OC}^{3}$ & $\%$ & 26.3 & 12.8 & 0.8 & 1.9 \\
\hline
\end{tabular}

${ }^{\mathrm{T}} \mathrm{CEC}$ : Cation exchange capacity, ${ }^{2} \mathrm{BS}$ : Base saturation, ${ }^{3} \mathrm{CO}:$ Organic carbon 
Table 3. Main species of the Forillon sugar maple forest.

Tree stratum: Abies balsamea, Acer saccharum, Betula alleghaniensis, Betula papyrifera (outside plot), Fraxinus (outside plot), Picea glauca, Populus balsamifera (outside plot).

Shrub stratum: Acer saccharum, Acer spicatum, Alnus alnobetula subsp. crispa, Cornus alternifolia, Corylus cornuta, Fraxinus, Lonicera canadensis, Populus balsamifera, Prunus pensylvanica, Ribes lacustre, Ribes triste, Rubus pubescens (subshrub), Sambucus pubens, Sorbus decora, Taxus canadensis.

Herb stratum: Actaea pachypoda, Aralia nudicaulis, Clintonia borealis, Cystopteris fragilis, Dryopteris carthusiana, Epipactis helleborine, Gymnocarpium disjunctum, Lysimachia borealis, Maianthemum racemosum subsp. racemosum, Osmunda cinnamomea, Phegopteris connectilis, Thalictrum dioicum.

Mosses stratum: Brachythecium sp., several liverworts.

Epiphytes: Lobaria pulmonaria and several mosses bryophyte on large sugar maple trunks. 
Table 4. Minimal date of tree establishment in the Forillon sugar maple stand.

Acer saccharum : 1886, 1888, 1892, 1903, 1916, 1918, 1919, 1920, 1923, 1924, 1928, 1928, 1929, 1930 , 1933, 1936, 1936.

Betula alleghaniensis : 1917, 1928, 1939, 1947.

Betula papyrifera : 1916, 1947.

Abies balsamea : 1945, 1954.

Picea glauca : 1874, 1882, 1890, 1917, 1927. 
Table 5. Number of charcoal pieces in function of species and microsites.

\begin{tabular}{|c|c|c|c|c|c|c|c|c|c|c|c|}
\hline \multirow{2}{*}{ identification } & \multicolumn{11}{|c|}{ microsite } \\
\hline & 7 & 8 & 9 & 10 & 13 & 14 & 16 & 18 & 20 & 22 & 24 \\
\hline Picea sp. & 1 & 0 & 0 & 0 & 0 & 0 & 1 & 1 & 0 & 0 & 0 \\
\hline Abies sp. & 0 & 0 & 0 & 0 & 0 & 4 & 0 & 0 & 0 & 0 & 0 \\
\hline Acer saccharum & 0 & 0 & 57 & 0 & 58 & 0 & 0 & 0 & 1 & 2 & 1 \\
\hline Acer sp. & 0 & 0 & 0 & 0 & 11 & 0 & 0 & 0 & 0 & 0 & 0 \\
\hline Conifer & 0 & 0 & 0 & 0 & 0 & 1 & 0 & 0 & 0 & 0 & 0 \\
\hline Broadleaf & 0 & 0 & 1 & 1 & 13 & 0 & 0 & 0 & 1 & 0 & 0 \\
\hline Unidentified & 0 & 0 & 0 & 4 & 63 & 0 & 0 & 1 & 24 & 0 & 0 \\
\hline
\end{tabular}


Table 6. ${ }^{14} \mathrm{C}$ date BP, calibrated date and botanic identification of charcoal pieces and number of fire in the Forillon sugar maple forest site.

\begin{tabular}{|c|c|c|c|c|c|c|c|c|c|}
\hline \multirow[b]{2}{*}{$\begin{array}{l}\text { Laboratory } \\
\text { number } \\
\text { (UCIAMS) }\end{array}$} & \multirow[b]{2}{*}{$\begin{array}{c}\text { micros } \\
\text { ite }\end{array}$} & \multirow[b]{2}{*}{ core } & \multirow[b]{2}{*}{$\begin{array}{l}{ }^{14} \mathrm{C} \pm \sigma \\
\text { date } \mathrm{BP}\end{array}$} & \multirow[b]{2}{*}{ Taxon } & \multicolumn{4}{|c|}{ Calibrated radiocarbon date } & \multirow{2}{*}{ 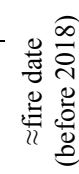 } \\
\hline & & & & & $\begin{array}{c}\text { Best } \\
\text { interval }\end{array}$ & median & probability & $\begin{array}{c}\mathrm{n} \\
\text { cumulated } \\
\text { fire }\end{array}$ & \\
\hline 189881 & 9 & $\mathrm{~B}$ & Modern & Broadleaf & & & & & \\
\hline 192926 & 20 & A & Modern & cf. Acer saccharum & & & & & \\
\hline 192927 & 20 & $\mathrm{~B}$ & Modern & Broadleaf & & & & & \\
\hline 192929 & 22 & $\mathrm{~B}$ & modern & Acer saccharum & & & & & \\
\hline 189915 & 9 & A & $115 \pm 20$ & Acer saccharum & $55-145$ & 100 & 0.57 & 12 & \\
\hline 189878 & 9 & A & $120 \pm 15$ & Acer saccharum & $59-144$ & 100 & 0.60 & 12 & \\
\hline 191346 & 13 & $\mathrm{C}$ & $125 \pm 15$ & Acer saccharum & $59-146$ & 100 & 0.57 & 12 & 165 \\
\hline 189909 & 13 & A & $130 \pm 20$ & Unindentified & $59-149$ & 105 & 0.49 & 12 & \\
\hline 191348 & 13 & $\mathrm{C}$ & $135 \pm 15$ & Acer saccharum & $64-118$ & 90 & 0.31 & 12 & \\
\hline 191317 & 13 & A & $145 \pm 15$ & Unindentified & $172-225$ & 200 & 0.36 & 11 & \\
\hline 189880 & 9 & A & $150 \pm 15$ & Acer saccharum & $170-224$ & 195 & 0.43 & 11 & \\
\hline 189883 & 9 & $\mathrm{C}$ & $150 \pm 15$ & Acer saccharum & $170-224$ & 195 & 0.43 & 11 & \\
\hline 189911 & 13 & A & $150 \pm 15$ & Acer saccharum & $170-224$ & 195 & 0.43 & 11 & \\
\hline 191332 & 13 & $\mathrm{~B}$ & $150 \pm 20$ & cf, Acer saccharum & $169-228$ & 200 & 0.39 & 11 & \\
\hline 189917 & 9 & A & $155 \pm 20$ & Acer saccharum & $168-225$ & 195 & 0.43 & 11 & \\
\hline 189908 & 13 & $\mathrm{~A}$ & $155 \pm 15$ & Acer saccharum & $169-224$ & 195 & 0.49 & 11 & \\
\hline 189911 & 13 & $\mathrm{~A}$ & $155 \pm 20$ & Acer saccharum & $168-225$ & 195 & 0.43 & 11 & \\
\hline 191316 & 13 & A & $160 \pm 15$ & Bark & $169-222$ & 195 & 0.53 & 11 & \\
\hline 191344 & 13 & $\mathrm{C}$ & $160 \pm 15$ & Acer saccharum & $169-222$ & 195 & 0.53 & 11 & \\
\hline 189879 & 9 & A & $165 \pm 15$ & Acer saccharum & $168-220$ & 195 & 0.55 & 11 & \\
\hline 191331 & 13 & $\mathrm{~B}$ & $165 \pm 15$ & Bark & $168-220$ & 195 & 0.55 & 11 & \\
\hline 189882 & 9 & B & $170 \pm 15$ & Acer saccharum & $168-219$ & 195 & 0.55 & 11 & 255 \\
\hline 191342 & 13 & B & $170 \pm 15$ & Unindentified & $168-219$ & 195 & 0.55 & 11 & \\
\hline 192921 & 14 & A & $170 \pm 15$ & cf. Abies sp. & $168-219$ & 195 & 0.55 & 11 & \\
\hline 189876 & 9 & A & $175 \pm 15$ & Acer saccharum & $167-217$ & 190 & 0.54 & 11 & \\
\hline 189912 & 13 & $\mathrm{~A}$ & $175 \pm 15$ & Acer saccharum & $167-217$ & 190 & 0.53 & 11 & \\
\hline 189916 & 13 & A & $175 \pm 20$ & Acer saccharum & $163-221$ & 190 & 0.51 & 11 & \\
\hline 191329 & 13 & $\mathrm{~B}$ & $185 \pm 15$ & Acer saccharum & $163-215$ & 190 & 0.48 & 11 & \\
\hline 191318 & 13 & $\mathrm{~B}$ & $190 \pm 15$ & Broadleaf & $146-189$ & 170 & 0.47 & 11 & \\
\hline 192919 & 13 & $\mathrm{C}$ & $190 \pm 15$ & Broadleaf & 146-189 & 170 & 0.47 & 11 & \\
\hline 189877 & 9 & $\mathrm{~A}$ & $195 \pm 20$ & Acer saccharum & $145-214$ & 180 & 0.60 & 11 & \\
\hline 191330 & 13 & $\mathrm{~B}$ & $195 \pm 15$ & Acer saccharum & $147-188$ & 170 & 0.50 & 11 & \\
\hline 192920 & 14 & A & $195 \pm 15$ & Conifer & $147-188$ & 170 & 0.50 & 11 & \\
\hline 191343 & 13 & B & $220 \pm 20$ & Acer saccharum & $272-304$ & 290 & 0.45 & 10 & \\
\hline 191334 & 13 & B & $230 \pm 20$ & Bark & $280-306$ & 295 & 0.58 & 10 & 355 \\
\hline 191341 & 13 & B & $260 \pm 15$ & Acer saccharum & $285-314$ & 300 & 0.97 & 10 & \\
\hline 191347 & 13 & $\mathrm{C}$ & $300 \pm 20$ & Unindentified & $353-435$ & 395 & 0.72 & 9 & 465 \\
\hline 191345 & 13 & $\mathrm{C}$ & $311 \pm 15$ & Bark & $355-434$ & 395 & 0.77 & 9 & \\
\hline 192930 & 24 & $\mathrm{C}$ & $375 \pm 15$ & cf.Acer saccharum & $432-499$ & 465 & 0.76 & 8 & 535 \\
\hline 192928 & 20 & B & $1175 \pm 15$ & Unindentified & $935-1100$ & 970 & 0.84 & 7 & 1035 \\
\hline 192925 & 20 & A & $1211 \pm 15$ & Unindentified & $1168-1181$ & 1125 & 0.99 & 6 & \\
\hline 189890 & 11 & B & $1215 \pm 15$ & Broadleaf & $1170-1164$ & 1115 & 0.82 & 6 & 1185 \\
\hline 189888 & 11 & A & $1280 \pm 15$ & Unindentified & $1223-1275$ & 1250 & 0.59 & 5 & \\
\hline 189907 & 11 & $\mathrm{C}$ & $1315 \pm 20$ & Unindentified & $1235-1292$ & 1265 & 0.79 & 5 & \\
\hline 189896 & 11 & B & $1355 \pm 15$ & Unindentified & $1275-1301$ & 1290 & 1 & 5 & 1335 \\
\hline 189889 & 11 & A & $1360 \pm 20$ & Unindentified & $1272-1305$ & 1290 & 1 & 5 & \\
\hline 192922 & 16 & B & $7390 \pm 20$ & Picea sp. & $8171-8223$ & 8195 & 0.54 & 4 & 8265 \\
\hline 192924 & 18 & B & $7715 \pm 20$ & Picea sp. & $8432-8544$ & 8490 & 1 & 3 & 8555 \\
\hline 189187 & 7 & A & $7840 \pm 25$ & Picea sp. & $8553-8651$ & 8600 & 0.96 & 2 & 8665 \\
\hline 192923 & 18 & A & $8035 \pm 20$ & Unindentified & 8968-9014 & 8990 & 0.62 & 1 & 9055 \\
\hline
\end{tabular}


Table 7. Estimate, standard error (s.e.) and $95 \%$ confidence interval (95\% C.I.) of parametric estimator (Homogene) and nonparametric (Chaol-bc, ACE-1, jackknife-1 and 2) of the number of theoretical fire events that occurred at the Forillon site.

\begin{tabular}{lccc}
\hline Estimator names & estimate & s.e. & $95 \%$ C.I. \\
\hline Homogenous & 12.3 & 0.6 & $12.0-15.4$ \\
Chaol-bc & 16.9 & 5.4 & $12.8-40.3$ \\
ACE-1 & 19.8 & 7.5 & $13.6-50.3$ \\
Jackknife-1 & 21.5 & 1.6 & $13.6-67.4$ \\
Jackknife-2 & 17.9 & 3.4 & $14.0-28.9$ \\
\hline
\end{tabular}


Figure 1. Location of the study site in the Gaspé Peninsula (eastern Canada-- see map inset at top right). The map was created using ArcGIS 10.3 based on data of eco-forestry maps (Ministère des Forêts, de la Faune et des Parcs du Québec, 2017).

Figure 2. Main soil profiles of the Forillon sugar maple forest. A. Upper solum heavily disturbed by earthworms where the original organic, Ae and B horizons were transformed in an homogeneous Ah horizon. B. Undisturbed, upper podzol solum showing the normal soil sequence of FH, Ae and B horizons. (Photo credit: S. Payette). The natural podzolic soil now covers a very small area in the forest site.

Figure 3. Tree size structure of the Forillon sugar maple forest.

Figure 4. Macroremain distribution of Forillon sugar maple forest according to decomposition (A) and burial (B) classes.

Figure 5. Distribution of the sum of cumulated probabilities of calibrated ${ }^{14} \mathrm{C}$ charcoal dates for the Forillon sugar maple site. Grey shadings correspond to probability areas showing the time intervals of fire dates based on the greatest probability distribution. Each sign + indicates the occurrence of a fire event centered on the mean of the greatest probability interval of one or several radiocarbon dates. 


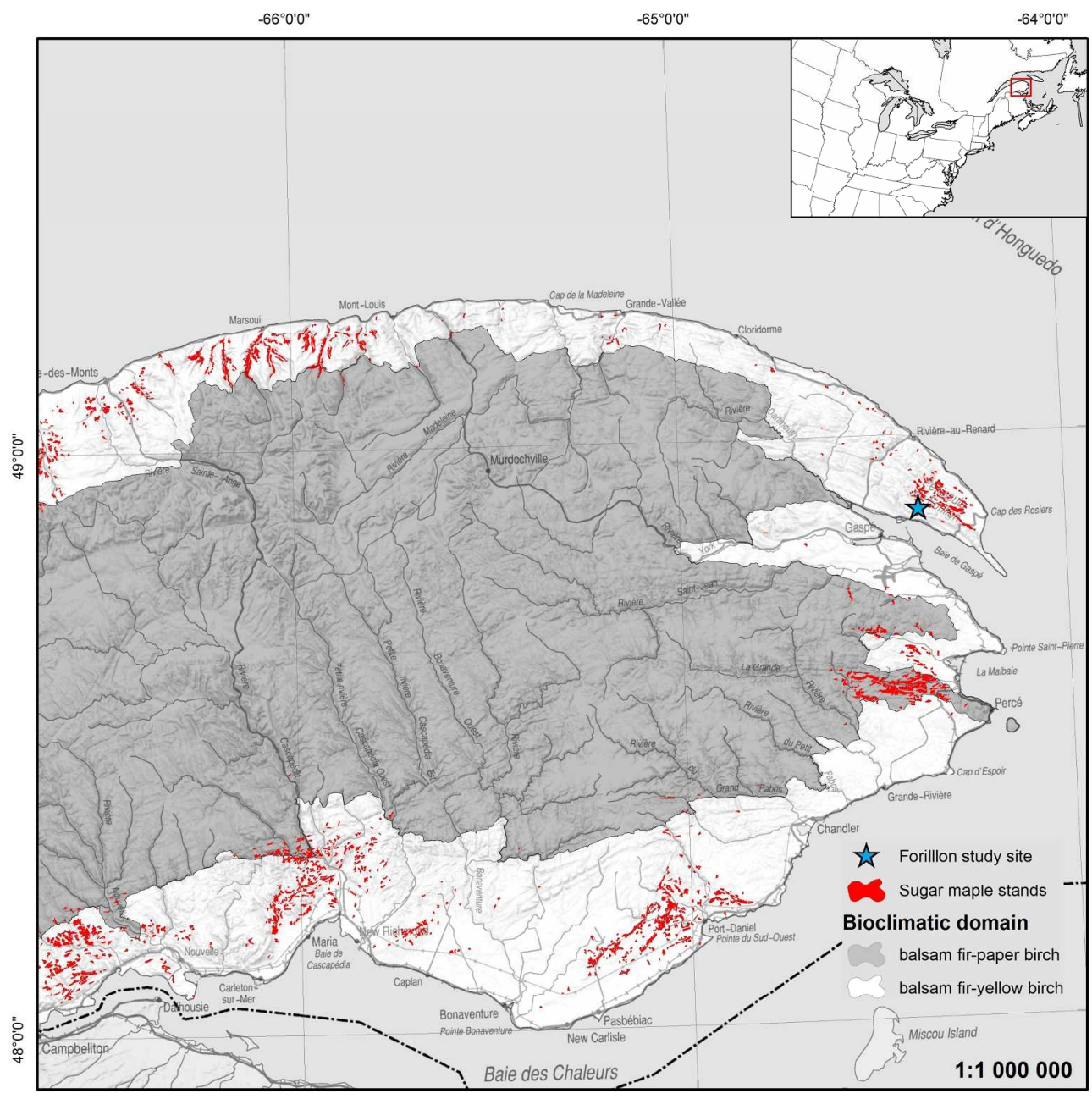

Location of the study site in the Gaspé Peninsula (eastern Canada-- see map inset at top right). The map was created using ArcGIS 10.3 based on data of eco-forestry maps (Ministère des Forêts, de la Faune et des Parcs du Québec, 2017).

$210 \times 210 \mathrm{~mm}(300 \times 300 \mathrm{DPI})$ 


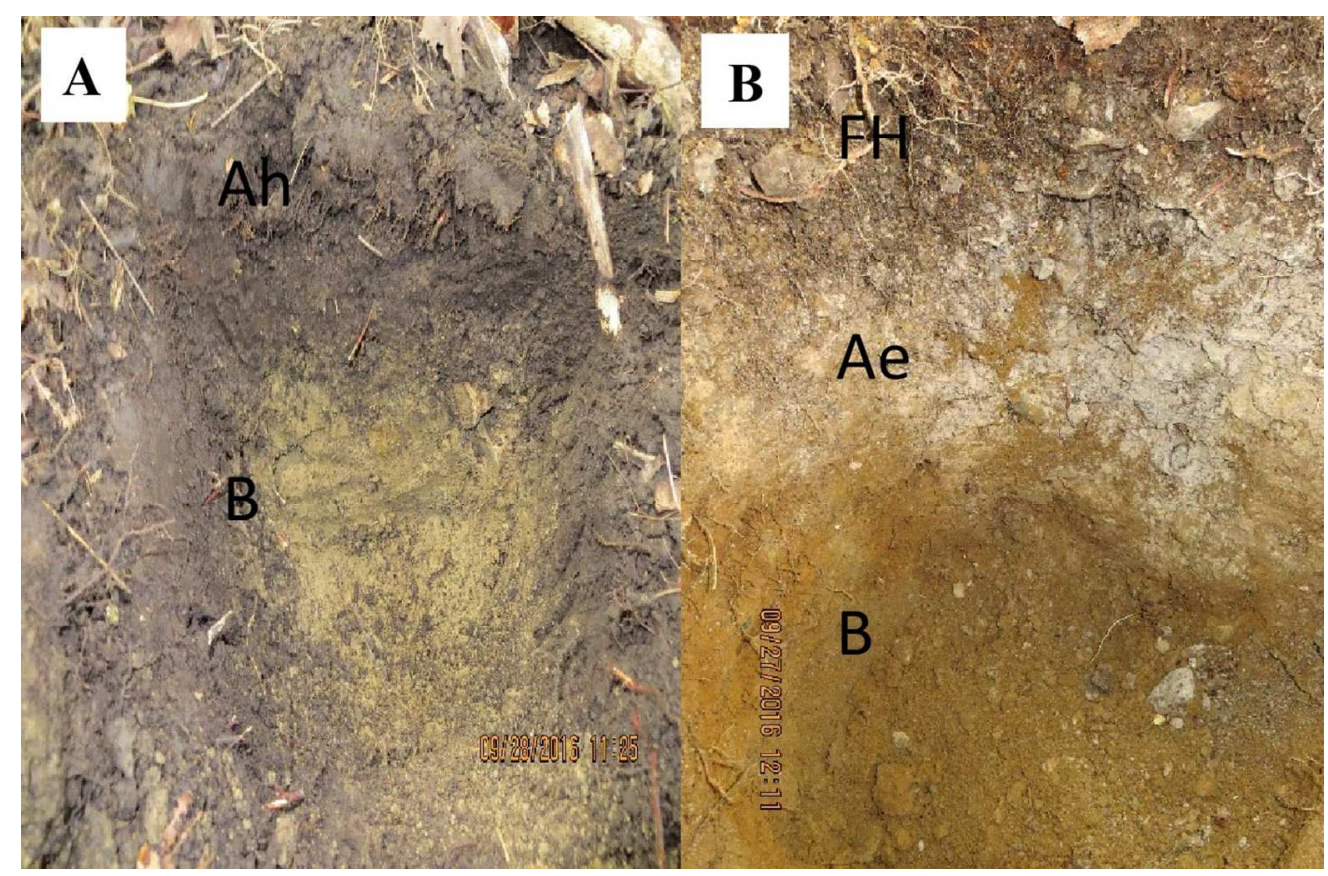

Main soil profiles of the Forillon sugar maple forest. A. Upper solum heavily disturbed by earthworms where the original organic, Ae and B horizons were transformed in an homogeneous Ah horizon. B. Undisturbed, upper podzol solum showing the normal soil sequence of $\mathrm{FH}, \mathrm{Ae}$ and $\mathrm{B}$ horizons. (Photo credit: S. Payette). The natural podzolic soil now covers a very small area in the forest site.

$118 \times 77 \mathrm{~mm}(300 \times 300 \mathrm{DPI})$ 


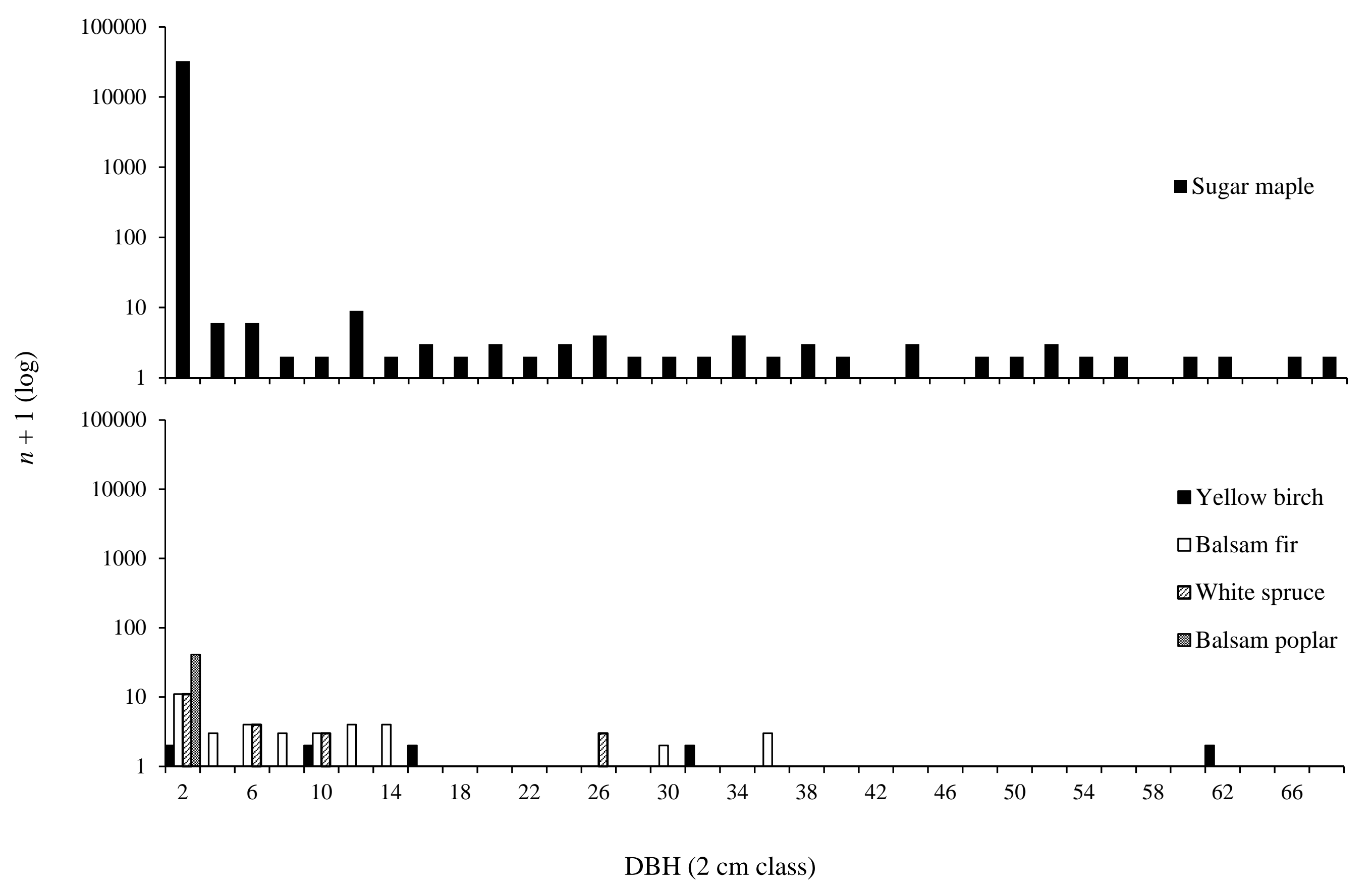



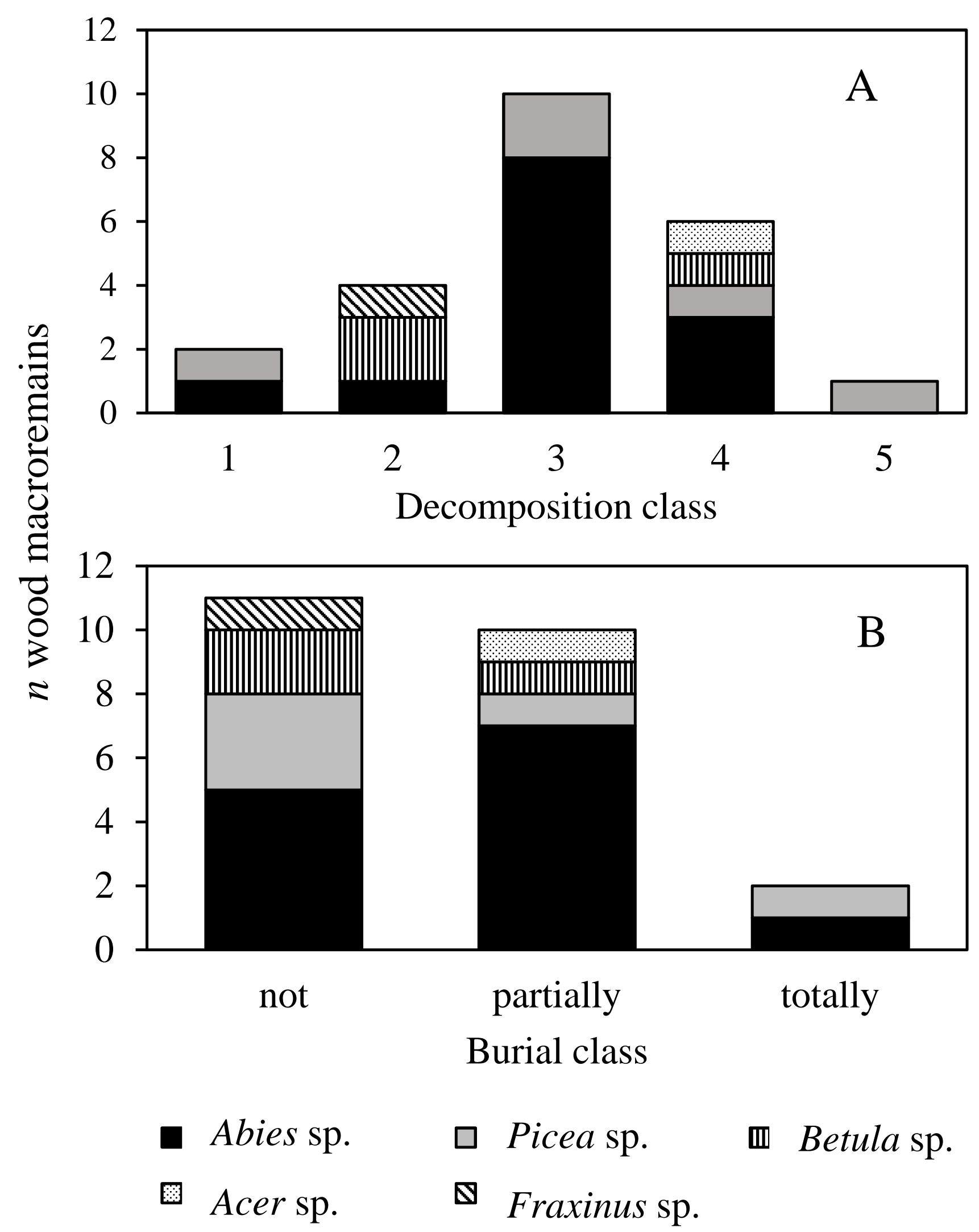


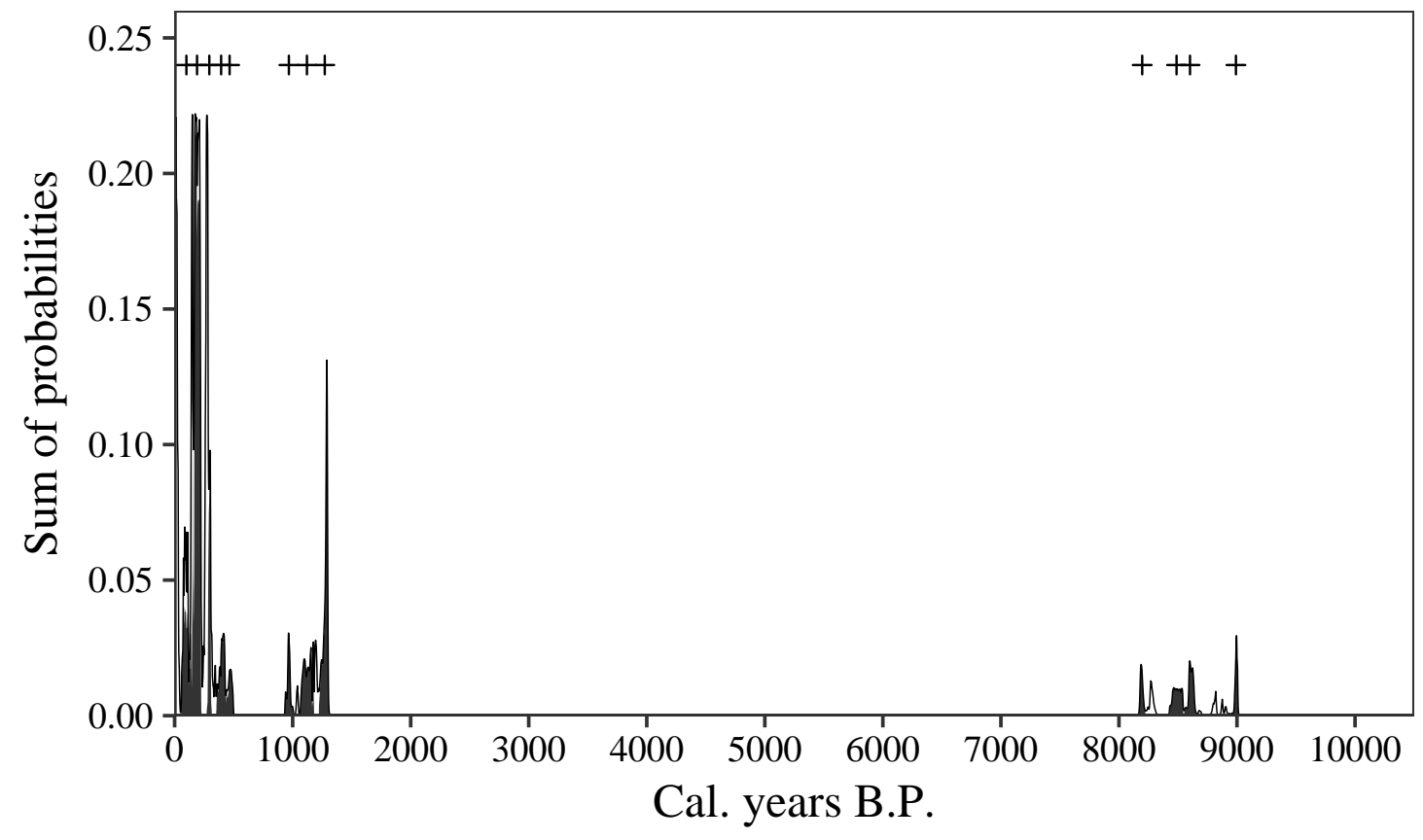

https://mc06.manuscriptcentral.com/botany-pubs 